\title{
Comments on Uncertainty in Groundwater Governance in the Volcanic Canary Islands, Spain
}

\section{Emilio Custodio ${ }^{1}$, María del Carmen Cabrera ${ }^{2, *}$, Roberto Poncela ${ }^{3}$, Tatiana Cruz-Fuentes ${ }^{2}$, Gema Naranjo ${ }^{2}$ and Luis Olavo Puga de Miguel ${ }^{4, \dagger}$}

1 Department of Geo-Engineering, Technical University of Catalonia (UPC), Jordi Girona, 1-3, Barcelona ES-08034, Spain; E-Mail: emilio.custodio@upc.edu

2 Departamento de Física (GEOVOL), Universidad de las Palmas de Gran Canaria, Campus Universitario de Tarifa, Las Palmas de Gran Canaria ES-35017, Spain; E-Mails: tcruz@proyinves.ulpgc.es (T.C.-F.); gnaranjo@proyinves.ulpgc.es (G.N.)

3 Hydrogelogist-Consultant, Santa Cruz de Tenerife 38111, Spain; E-Mail: rponcela_geo@yahoo.es

4 La Laguna University, La Laguna (Tenerife) 38001, Spain; E-Mail: lpugmig@gmail.com

$\dagger$ Retired.

* Author to whom correspondence should be addressed; E-Mail: mcarmen.cabrera@ulpgc.es; Tel.: +34-928-454-478; Fax: +34-928-452-922.

Academic Editor: Athanasios Loukas

Received: 30 March 2015 / Accepted: 8 June 2015 / Published: 17 June 2015

\begin{abstract}
The uncertainty associated with natural magnitudes and processes is conspicuous in water resources and groundwater evaluation. This uncertainty has an essential component and a part that can be reduced to some extent by increasing knowledge, improving monitoring coverage, continuous elaboration of data and accuracy and addressing the related economic and social aspects involved. Reducing uncertainty has a cost that may not be justified by the improvement that is obtainable, but that has to be known to make the right decisions. With this idea, this paper contributes general comments on the evaluation of groundwater resources in the semiarid Canary Islands and on some of the main sources of uncertainty, but a full treatment is not attempted, nor how to reduce it. Although the point of view is local, these comments may help to address similar situations on other islands where similar problems appear. A consequence of physical and hydrological uncertainty is that different hydrogeological and water resource studies and evaluations may yield different results. Understanding and coarsely evaluating uncertainty helps in reducing administrative
\end{abstract}


instability, poor decisions that may harm groundwater property rights, the rise of complaints and the sub-optimal use of the scarce water resources available in semiarid areas. Transparency and honesty are needed, but especially a clear understanding of what numbers mean and the uncertainty around them, to act soundly and avoid conflicting and damaging rigid attitudes. However, the different situations could condition that what may be good in a place, may not always be the case in other places.

Keywords: uncertainty; groundwater; governance; Canary Islands

\section{Introduction}

Natural processes and natural behavior are essentially uncertain due to a stochastic component, which is always present at any spatial and time scale, even when they are well known and accurately measured. This uncertainty can be called essential or non-reducible. Other uncertainty components are added, often dominant ones under common circumstances. These are due to knowledge or epistemic deficiency, measurement and monitoring deviations, bias and errors. They are also due to the application of conceptual models that are inadequate or erroneous or that are based on insufficient analysis or a partial or too simplified consideration of the involved contributing processes. These last sources of uncertainty are often the dominant ones. A further kind of uncertainty is that derived from using falsified, invented data and concealed and deformed facts, which is unfortunately something that happens from time to time, if not the common situation in some cases. These non-essential kinds of uncertainty can be decreased with improved effort and care, although with increased human effort and time devoted to checking the data and results. However, the economic expenses involved may be high, and the cost could become excessive and disproportionate in the context and in the economic and social value of what has to be managed in a particular case. This is reflected in the popular saying: the perfect is the enemy of good.

All that has been said above is valid on hydrological grounds, and particularly for groundwater, despite that the data and results are often presented with many digits. Most of them are actually non-significant. Giving them communicates an illusory expectation of accuracy to non-experts and especially to those that make decisions and conform policies. Often, only two or three digits are valid and, in some cases, only one. It is important to calculate, show and internalize the real accuracy of the data and results.

Quite a large uncertainty is common in hydrometeorology, surface water hydrology and groundwater hydrology, as is the normal case in the evaluation of natural magnitudes, with different nuances in each case. In the two mentioned sciences, time variability has more weight than in groundwater hydrology (hydrogeology), in which land and ground properties play a dominant role in uncertainty. Furthermore, environmental, economic and social results, which are as or more important to water users and society, are quite uncertain.

Uncertainty can be measured by deviations from a centered value, such as the mean, median or mode. For data close to a normal (Gaussian) distribution, the uncertainty of a magnitude with mean value $m$ can be measured by the standard deviation $(\sigma)$ and be given as $m \pm \sigma$ (comprising $68.3 \%$ of the possible 
realizations) or as $m \pm 2 \sigma$ (comprising $95.4 \%$ of possible realizations). It can be also given as dimensionless as $m / \sigma$, which is called the coefficient of variation (CV), as an absolute value or as a percent. For non-normal data distributions that cannot be mathematically transformed into a normal one, uncertainty can be measured as the difference between to symmetrical percentiles, such as $20 \%$ and $80 \%$, and refers to the median as a centered value. When data do not form series with at least a few terms or concepts that cannot be quantified, uncertainty is appreciated. As much as possible, it is convenient to qualify these data according to some references or categories in order to get an approximate semi-quantified value.

The uncertainty of some calculation results can be obtained from the squared root of their statistical variance. In the case of normally-distributed variables, the variance of a calculated result is the weighted sum of the variances of the different variables involved, following the error propagation rule. In the case of closed formulae, the variances and the respective weighting factors can be readily obtained by calculation, but in more complex cases, a sensitivity analysis and expert evaluation of the variable variances and the weighting factors are required.

The object of this paper is neither to advance the study of uncertainty in water and groundwater resources, which is developed in a large number of recent publications, such as [1-5], and many others, nor to provide a detailed analysis of hydrological, economic and social uncertainty components, but to comment on the actual circumstances on the Canary Islands. The Canary Islands, besides the local interest, present circumstances that are also found on other high volcanic and non-volcanic islands in arid and semiarid areas. Commenting on their circumstances may help to solve or avoid some groundwater governance problems in other areas, taking care of the sometimes dominant influence of the local framework. Thus, the contents do not present a systematic analysis, nor quantitative considerations, nor the way to solve accuracy aspects, but just problems found in practice. They may be relevant in many situations in the semiarid part of Europe as a result of the application of the European Water Framework Directive by many untrained water authorities or poorly-informed politicians.

Thus, this paper deals with the uncertainty problems in the particular case of the Canary Islands, due to their special conditions for water governance, which are more clear cut than in other areas of Spain. The MASE project (Minería del Agua Subterránea en España (Groundwater Mining in Spain)) [6] has focused on the Canary Islands, in addition to southeastern continental Spain, to collect and analyze information [7]. Most comments refer to Gran Canaria and Tenerife Islands, which are the main islands according to their economic output and population, with important intensive groundwater use.

\section{The Canary Islands}

The Canary Islands (the Canaries) are a volcanic archipelago of the region known as Macaronesia, consisting of seven major islands and a few small isles and islets. They are located in the eastern Atlantic Ocean, between $27^{\circ} 37^{\prime}$ and $29^{\circ} 25^{\prime} \mathrm{N}$ and $13^{\circ} 20^{\prime}$ and $18^{\circ} 10^{\prime} \mathrm{W}$, across from the Saharan coast of Africa (Figure 1). Along a length of $400 \mathrm{~km}$ from east to west, the islands are Lanzarote (LZ), Fuerteventura (FV), Gran Canaria (GC), Tenerife (TF), La Gomera (GO), La Palma (LP) and El Hierro (HI). There are large economic, population and physical variations from island to island. The Canary Islands are one of the Autonomous Regions of Spain. The total surface area is $7447 \mathrm{~km}^{2}$. About 2.2 million inhabitants live on them, plus a large number of tourist visitors year-round. 

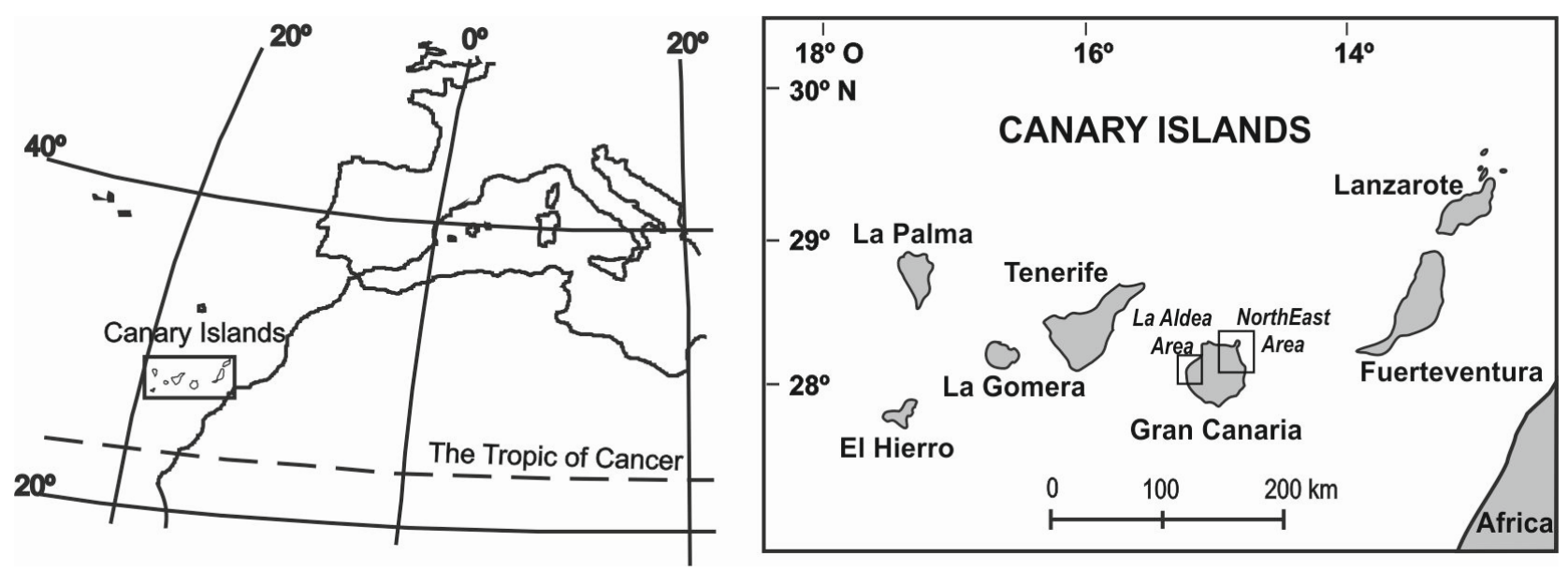

Figure 1. Situation of the Canary Islands. The location of the example areas in Gran Canaria mentioned in the text are shown.

Stressed water conditions dominate, and intensive groundwater exploitation is common, even with groundwater mining [8]. From the hydrogeological point of view, the islands consist of a low permeability volcanic core, covered and surrounded by younger, more permeable, heterogeneous volcanic materials and some derived sediments. Circumstances vary from island to island and from site to site. Groundwater flows towards the coast, and on the way down, under the original natural conditions, spring areas appeared and fed some permanent flows in some tracts of the deep gullies. They have mostly disappeared due to intensive groundwater development.

Besides direct channeling of spring water, where it is still available, groundwater is intensively developed through horizontal and vertical works. Horizontal works consist of tunnels (water galleries) penetrating deep enough to intersect the water saturated formations at the moment; they are more developed in Tenerife. Vertical works are deep, large diameter wells (Canarian wells), excavated using mining technology. Both of them may contain secondary works, mainly water galleries and small diameter, long horizontal boreholes to increase the chance of intersecting permeable features. More recently, deeply-penetrating, mechanically-drilled wells have been introduced or used to deepen existing Canarian wells. Seawater desalination was introduced to Lanzarote in the early 1960s and in the early 1970s to Gran Canaria. All of this water is now commonly used for urban supply and for irrigation of cash crops. In addition, brackish groundwater is freshened by means of reverse osmosis or electrodialysis, mostly for crop irrigation in small, private facilities. Reclamation of treated urban waste water for agricultural uses started in the late 1970s, but its development is lagging behind expectations. Groundwater is the most important natural water resource in the high islands and the dominant one, greater than sea water desalination and still less expensive, in spite of the extreme conditions for obtaining it [6,7]. Groundwater development by means of galleries and wells started in the late 19th century and become intensive after 1930 and especially in the period 1950-1970.

Administratively, each island is currently a separate water district (Consejo Insular de Aguas or Insular Water Council). The variable island circumstances create special conditions for water governance. Local water legislation follows, but is different from, the Spanish Water Act to consider the special circumstances in the islands. Currently it incorporates the European Water Framework Directive, mostly 
through the Spanish Water Act, as the Canarian Parliament has not yet enacted a review of their previous water law.

Table 1 summarizes the estimated water resources in the 2000-2010 decade, after groundwater extraction started to decrease.

Table 1. Average water resources in the 2000-2010 decade, when groundwater extraction started to decrease and the use of reserves was dwindling. Values in $\mathrm{hm}^{3} /$ year $\left(1 \mathrm{hm}^{3}=1\right.$ cubic hectometer $=1$ million $\left.\mathrm{m}^{3}=1 \times 10^{6} \mathrm{~m}^{3}\right)$. Data come from the 2010 Island Water Plans. Data may vary according to the report and author and are the result of applying non-uniform methodologies. They are given only to show the order of magnitude. Uncertainty has not been given, but it is high. LZ, Lanzarote; FV, Fuerteventura; GC, Gran Canaria; TF, Tenerife; GO, La Gomera; LP, La Palma; HI, El Hierro.

\begin{tabular}{|c|c|c|c|c|c|c|c|c|}
\hline Island & $\mathbf{L Z}$ & FV & GC & TF & GO & $\mathbf{L P}$ & HI & Total \\
\hline \multicolumn{9}{|c|}{ Total Water } \\
\hline Precipitation & 134 & 184 & 466 & 865 & 140 & 518 & 101 & 2408 \\
\hline Surface runoff & 1.3 & 5 & 75 & 20 & 8 & 1.5 & 0.6 & 111 \\
\hline Recharge & 3.3 & 14 & 87 & 239 & 63 & 265 & 27 & 642 \\
\hline \multicolumn{9}{|c|}{ Available Resources } \\
\hline Surface water & 0.1 & 0.0 & 24 & 0.0 & 1.4 & 0 & 0 & 25 \\
\hline Groundwater & 0.5 & 2 & $100 *$ & $180 *$ & 4.5 & 58 & 2.4 & $347 *$ \\
\hline Springs & 0 & 0.0 & 0.1 & 5 & 7 & 10 & 0 & 22 \\
\hline Seawater desalination & 19 & 12 & 60 & 19 & 0 & 0 & 0.5 & 110 \\
\hline Brackish water desalination & 0.5 & 2 & 18 & 0 & 0 & 0 & 0 & 20 \\
\hline Reuse & 0 & 0 & 12 & 8 & 0 & 0 & 0.4 & 20 \\
\hline
\end{tabular}

Note: * A significant fraction comes from the depletion of groundwater reserves.

\section{Considerations on Some Uncertainty Components of Groundwater Resources Evaluation in Gran Canaria and Tenerife}

Many situations and facts contribute to knowledge and management uncertainty. They influence water governance. It is difficult to analyze them briefly; they are not treated systematically, but only those that are considered relevant in the local circumstances are discussed. Some aspects are highlighted as those that contribute the most under common circumstances. For the sake of brevity, only some of the components that refer to the evaluation of groundwater resource quantity will be considered, leaving aside those related to water salinity and quality, which are more complex, although not less important and a growing concern, and these also are an essential part or water governance.

Groundwater resources are generally quantified by a water balance of the aquifer or aquifer system. The water balance has four main general components: recharge, discharge, storage change and water exchange with other units in the ground. The balance is carried out in a given volume, so boundary conditions are often important to define some terms. Boundary and aquifer conditions are often difficult to define and may greatly contribute to uncertainty. Furthermore, hydrological boundaries may greatly differ from administrative and political boundaries that have to be adopted in practice. The use of political boundaries, often demanded by politicians and the water administration, increases uncertainty, as conditions within these boundaries are difficult to clearly and accurately define from a 
hydrogeological point of view, both for direct use or to split results obtained when hydrological boundaries are used. This is often a serious cause of litigation unless rules to resolve partitions that are not clearly defined by applying hydrological reasoning.

On the Canary Islands, each island as a whole has a well-defined boundary at the coast line, but when a part of it has to be considered (e.g., when the scale of study is decreased), problems in defining appropriate boundary conditions appear [9-11].

Recharge is often the most difficult to evaluate for the water balance, as the wide time and space variability of precipitation and atmospheric conditions combines with large land, terrain and vegetal cover variability. Recharge evaluation is an important scientific and technical challenge that is accompanied by a noticeable uncertainty in all of its aspects. The quantification of recharge can be undertaken through a wide set of methods, but which are not equivalent among themselves, as the results they yield depend on the spatial and time scale. Calculations involve assumptions of the processes and the estimation of local and lumped physical parameters, sometimes risky ones, whose uncertainty increases the more the terrain differs from a homogeneous granular one. To increase the accuracy, independent methods have to be applied, if possible. Diverse general publications present different recharge evaluation and calculation methods [12-17]. For a relatively large territory, the possible methods to calculate recharge from precipitation reduce to soil water balance, balance of atmospheric chloride deposition, water table fluctuations, numerical modeling and, recently, satellite-based observations. They are not always applicable and may yield different results (net and total recharge, time variable recharge or long-term average recharge). Another problematic aspect can be the calibration, which is not always possible in some of the methods. In some cases, uncertainty can be restricted by using other more detailed associated methodologies. Rainfall recharge may be made more complex for evaluation when soil and rock discontinuities favor recharge, avoiding soil storage. In some circumstances, concentrated recharge from surface water bodies and rivers may be important, especially the more arid the climate is. This recharge involves high uncertainty, especially for ephemeral flows. Recharge resulting from excess irrigation water may become important in many areas, and the uncertainty of water application is a new component to be considered.

Recharge uncertainty is especially acute in the Canary Islands due to conspicuous altitudinal changes, extensive areas of dissected relief and important geological changes. To increase accuracy, much territorial detail is needed, but in reality, there is not enough meteorological data, even if the actual density of stations is in general greater than what is common in continental Spain and on most islands. Increasing the number of meteorological stations is too costly. On the Canary Islands, recharge is derived from rainfall infiltration, with a small effect of snow and surface water infiltration. However, storm runoff is sporadically produced, which may have some relevance in water resources, especially in some areas of Gran Canaria Island, as well as the recharge produced by return irrigation flows in the peripheral agricultural areas of Gran Canaria, Tenerife and La Palma Islands. Gauging the many small, ephemeral and sporadic gullies is too costly and even practically unfeasible. In the case that there are some dams to temporarily store water, there is the possibility to calculate occasional runoff, but the infiltration tract mostly remains unknown. These reservoir dams are rare, and in fact, they are only significant in Gran Canaria and La Gomera, where they are in the high parts; so, they only yield information in the headwaters in the infrequent cases in which they are monitored. This monitoring is not an easy task, because they usually also store groundwater from wells and water galleries. 
La Aldea aquifer, located at the west of Gran Canaria, is a good example of an aquifer that is isolated from the island's main aquifer and that needs specific water planning conditions. A numerical model allowed reducing and estimating recharge uncertainty (Figure 2). The La Aldea aquifer is highly sensitive to the hydraulic conductivity and storage coefficient of the basalts, the alluvial units and the scree deposits, so the uncertainty of these parameters has a large influence on the results and the derived decisions. Uncertainty has been reduced to some extent by considering salinity transport [18]. Measurement of these parameters by hydraulic tests is rarely feasible and at a high cost relative to the improvement in the results. The high groundwater salinity is the result of high evapoconcentration due to the aridity and the return irrigation flows in the agricultural areas using imported water and local groundwater, with variable proportions according to surface water availability each year. This helps to reduce the uncertainty of groundwater rainfall recharge relative to that of return irrigation flows and external water irrigation loses.
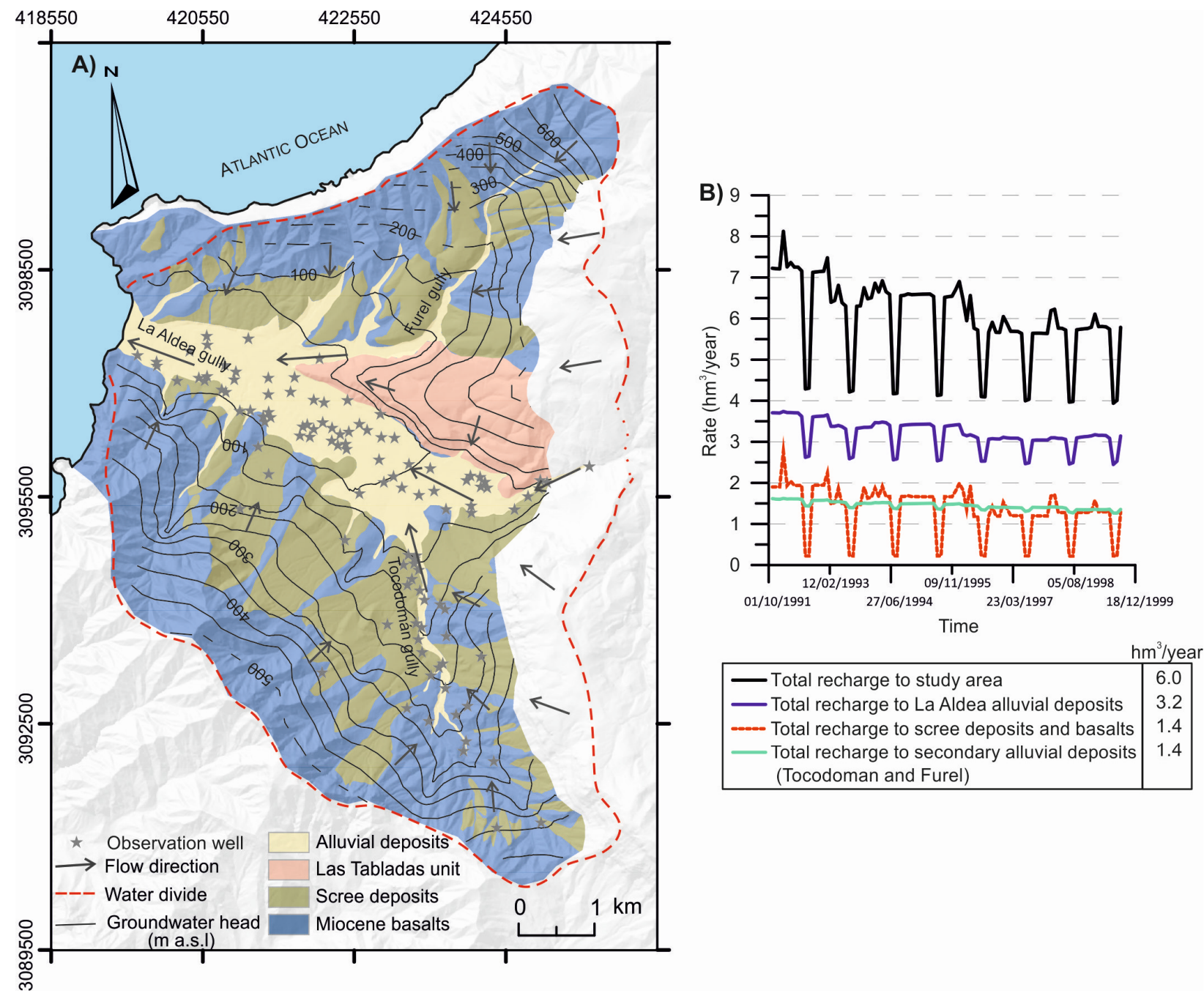

Figure 2. La Aldea area (NW of Gran Canaria). (A) Groundwater head contours (m asl) and flow paths corresponding to the 1991-1992 hydrologic year; (B) total recharge to the study area resulting from the hydrogeological model. Results depend highly on the variable yearly rainfall contribution, surface reservoir management, antecedent conditions and local decisions. 
Worldwide, the most used method for rainfall diffuse recharge evaluation at a large scale, which is needed for groundwater planning, is the soil water balance. Daily rainfall values are strictly needed in the case of arid and semiarid areas to get reliable results. Several calculation codes are available, using different approaches to the different processes involved. Results, even in relatively homogeneous areas, may be highly biased, as the parameters are often poorly known and sometimes reduce to best guesses. To refine the results, they have to be compared to groundwater data, mainly water table fluctuations and spring and river base flow records, to improve parameter values through calibration. This calibration, and the following validation, if enough data are available, along a sufficiently long time period, can be done to try to reproduce real data as best as possible [19], assuming that no significant changes in the aquifer state along time have been produced. To estimate the associated uncertainty, a sensitivity analysis is needed, but it is still poorly systematized and tedious, so it is rarely done. The main obstacle is getting reliable information on the variables' variance, which needs tests and a relatively high number of detailed studies in diverse parts of the area.

On the Canary Islands, the code Visual Balan [20] or the simpler one Easy-Bal developed by the "Curso Internacional de Hidrología Subterránea" have been used occasionally. On Tenerife Island, less detailed water balances have been applied in a dense network covering the whole island, similarly to the SIMPA technique of the Centro de Estudios Hidrográficos (CEDEX, Madrid, Spain). Calibration capability is a serious limitation on the Canary Islands, as continuous long records of frequently-measured water table changes are not available and probably will be not available due to the difficult local conditions. The water table is often very deep, which means that its reaction to recharge has a long delay and is highly smoothed, besides an important disturbance due to groundwater extraction and the effect of short-circuiting produced by the uncased wells. This makes recharge evaluation very uncertain, independent of the territorial detail and the efforts to improve monitoring.

Some preliminary attempts to evaluate recharge uncertainty through sensitivity analysis of daily water balance in the soil have been attempted in northern Gran Canaria [21]. Three catchments have been considered, and each of them has been divided into a low part (precipitation $<400 \mathrm{~mm} /$ year), a mid-part (precipitation between 400 and $600 \mathrm{~mm} /$ year) and a high part (precipitation $>600 \mathrm{~mm} /$ year). Natural recharge was calculated for the period 1980-2013 using Easy-Bal 3.0, which considers soil thickness, maximum soil water reserve and wilting point, daily precipitation and a threshold for runoff generation. Results are shown in Figure 3. Recharge is especially sensible to the maximum soil water reserve and the threshold for runoff generation. Defining averaged soil characteristics in a rather extensive area is difficult not only because of the high spatial variability, but also the thin, poorly-developed soils or their absence in parts of the water balance areas. This cannot be done by measurement, but through calibration, provided data are available. A deep water table and geological variability do not help, so uncertainty has to be coarsely estimated by comparing with other methods and, in the end, assumed as a reality to be incorporated in management and governance. 


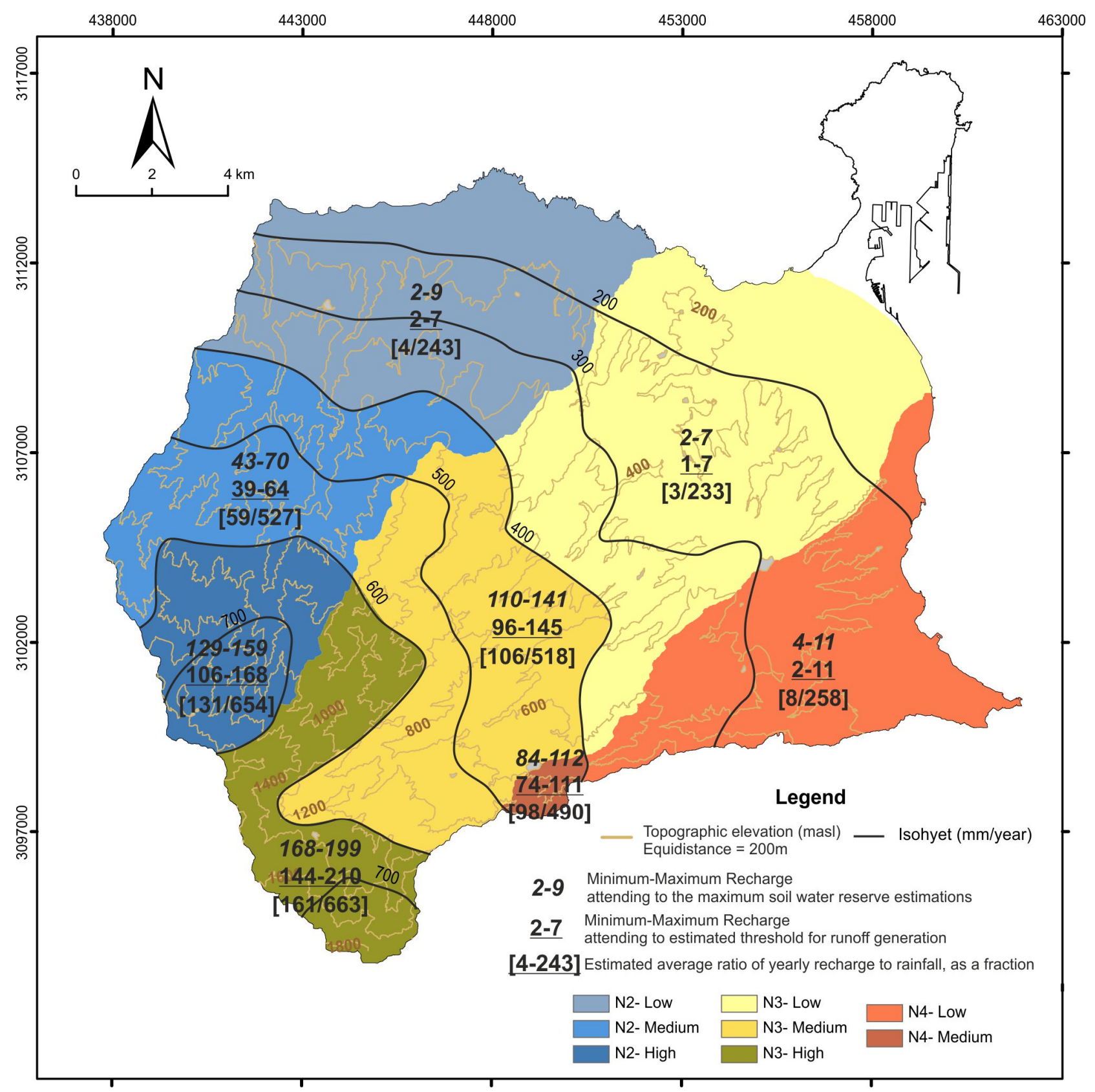

Figure 3. Preliminary recharge estimations in $\mathrm{mm} / \mathrm{year}$ in the northeast of Gran Canaria Island, extending from the coast to the top [21]. Recharge ranges shows the uncertainty that can be expected in each area according to the two most sensible parameters: maximum soil water reserve (in italics) and threshold for runoff generation (underscored). The third figure in brackets refers to the estimated average ratio of yearly recharge to rainfall, as a fraction. N2, N3 and N4 refer to catchment areas of the Water Plan.

Another method to estimate average multiannual recharge, independent of the soil water balance, is the chloride atmospheric deposition balance in the soil. This is a method for a large scale that lumps land properties to obtain averaged recharge values in the long term, but that has to be applied under steady conditions, without land use and climate changes in addition to no changes in the chloride concentration and storage along the flow path through the unsaturated zone [22]. A long sampling time is needed to get the needed data when they are not previously available. Although they are not always available for 
the Canary Islands, on northern Gran Canaria, their knowledge is quite advanced with interesting results [23] and with a preliminary uncertainty evaluation of the results [24]. There is also an application to the Las Cañadas aquifer on central Tenerife Island [25]. Results compare reasonably with what is obtained for the Iberian Peninsula as a whole [26] and at local level [27]. They have been partly developed inside the wider scope research Project REDESAC (www.redesac.upc.es). What is obtained is net average recharge, but under the prevailing deep water table conditions, net recharge coincides practically with total recharge. However, conditions leading to vadose zone lateral discharge to the deep gully canyons due to intercalated temporal and even permanent perched aquifers may reduce recharge significantly. Transit time through the vadose zone is of a few decades in the main recharge area, so recharge calculation is not biased if climate and land use conditions have not changed. Otherwise, serious errors can be produced, adding a serious, uncontrolled uncertainty. In the arid southern parts of the islands, the transit time through the vadose zone is much longer, so the method cannot be applied if conditions have not been steady for centuries or some millennia. A further cause that increases recharge uncertainty is the use of incorrect proxies for chloride concentration in recharge due to the slope effect. This can be corrected by using a corrected conceptual model, but this is not always evident.

Soil water balance methods [20] and the balance of atmospheric deposition of chloride need to be supported by a good conceptual model of aquifer functioning, resulting from the combination of geologic-hydrogeologic, hydrodynamic, hydrogeochemical and environmental isotope methods. This has often not been duly considered in official documents, and thus, uncertainty is increased by using non-validated conceptual models. Uncertainty can be reduced at a reasonable cost by choosing the correct conceptual flow and mass transport model. This can be accomplished by hydrochemical and environmental isotope studies.

The conceptual models of groundwater flow and salinity transport of the Canary Islands were firstly developed during the SPA-15 Project [28] and the studies that followed. They have been greatly improved later by continued university action [29,30], although there is still much to be done. Recharge by return irrigation flows, which is significant in many peripheral areas of Gran Canaria, Tenerife and La Palma Islands, is only known as a guess, although some local studies are available and used to refine the data, as in the La Aldea aquifer [18]. Furthermore, surface runoff is not adequately known. It is important for some areas of Gran Canaria Island, where it could be studied by monitoring the many storage reservoirs and derivation weirs existing there, but as already mentioned, this is a difficult task in practice, existing data being very scarce with only yield data for the high parts. These factors may have an important weight in water balances in diverse areas [31], even a dominant one, and their neglect contributes significantly to increasing uncertainty.

Furthermore, aquifer discharge is quite uncertain. It is often poorly identified, there are errors in natural or artificial discharge flow measurements or they are simply estimated with the help of simple calculations based on Darcy's law, especially when the discharge is produced in a large water body or as underground transfer to other aquifers.

Well and water gallery inventories are quite good on Gran Canaria, Tenerife and the other western islands when compared to other Spanish areas, but, even in this case, flows and their time changes are not accurately known and often depend on estimation or good-will declaration by well or water gallery owners. For local groundwater balances, they cannot be easily or clearly disaggregated. 
To close the balance, the changes of stored water volume in the aquifer have to be known. This requires adequate piezometric level monitoring of the appropriate number of points representing the water table elevation, besides a good knowledge of aquifer geometry. This evaluation requires a reasonably good knowledge of the drainable porosity (specific yield) in the fringe in which the water table varies, which change as the water table goes up and down. Drainable and fillable porosity has to be known, both in space and in depth.

On Gran Canaria and Tenerife, there is a continued consumption of dynamic groundwater reserves, so their evaluation is an important term in the water balance. The right value of drainable porosity is poorly known and varies depending on the volcanic formation and conspicuously with depth. The errors in groundwater reserve estimation may have a coefficient of variation that can be coarsely guessed to be of the order of 0.5 , which introduces a conspicuous uncertainty in the evaluation of groundwater resources.

Mathematical modeling of aquifer water flow provides powerful tools for groundwater resource evaluation, which is widely used, but the accuracy of the results depends on the difficult-to-define areal parameters and representative boundary conditions. Matching water balance values with hydrometric data allows their refinement through calibration and validation. This reduces the uncertainty of water resource evaluation under exploitation conditions and their evolution, with the possibility of predicting approximate future conditions under given scenarios, provided these scenarios do not differ essentially from the historical situations of calibration. Numerical models of groundwater flow may be greatly improved if a mass transport model can be additionally constructed and calibrated, for example for chloride [18].

Numerical groundwater models have been constructed for the whole island of Gran Canaria (old and rather obsolete) and of Tenerife (updated three times for the Water Plan) and also for some local areas, such as La Aldea Valley on Gran Canaria [9], Los Rodeos aquifer on Tenerife [11] and the Betancuria volcanic Massif on Fuerteventura [32]. However, all of these models give rather uncertain results due to the uncertainty of parameters and the scarce and sometimes low reliability of the data available for calibration. In the case of models of the whole island, the uncertainty linked to boundary conditions is small in reference to the coastal line position, but remains high for the flow domain depth. The latter is of moderate relevance for the inner parts of the island, but may be quite significant along the periphery, where groundwater outflows to the ocean. This is especially important for Tenerife Island. Along the coast, groundwater-seawater conditions are poorly known, and accuracy for island outflow is needed to evaluate and control coastal aquifer salinization, a serious and uncertain condition for some islands' areas. One of the weakest aspects is the poor knowledge of the hydraulic parameters of the geological formations. Their measurement is very difficult at the required scale, and knowledge of them is difficult to improve in practice. The current model of Tenerife Island is a good tool due to the progressive upgrading. It helps definitively in water planning and decision making when used with caution and when being aware of its notable limitations. The real role has to be viewed considering uncertainty. Therefore, the results are not accurate figures, but only reflect an improved approach that is nuanced by the estimation of associated uncertainty and has to be used carefully. It has to be clearly understood that other acceptable realizations and calibrations are possible, yielding different results. The model calibration that yields the minimum mathematical error is not necessarily the best one and sometimes may be a biased one. This is a well-known fact to many model users, as inverse calibration models do 
not appreciate details of significant importance, such as the rate of change, the depletion rate or a fast or delayed reaction to events, especially if they are not weighted and programmed [33]. This is related to the identifiability of models [34] and structural accuracy [35].

On Gran Canaria and especially on Tenerife Island, the results relative to water planning are very sensible to the depletion of groundwater reserves and the discharge into the sea along the coast. They are uncertain significant terms in the groundwater balance. Besides, the slow time evolution has a great relevance with respect to the evaluation of future scenarios. The components of the water balances are not steady-state ones, so they will evolve slowly, even if the conditions and forcing do not change. Whole island models yield a general picture of the water resource situation and allow preliminary with reference to local conditions. However, to address local hydrogeological conditions and water planning, caution is needed, as significant deviations may appear. This means that some further degree of local knowledge is often needed. This becomes more susceptible to deviations when results have to be referred to administrative, municipal or other political limits, as they often differ from hydrogeological boundaries. Thus, it is no surprise that the whole island model results differ to some extent, sometimes conspicuously, from what is obtained by mans of local, more detailed models, even if the distant, non-physical boundaries are taken from the whole island model [11]. This is an important aspect for groundwater policy and for the acceptability of the results by local authorities and water stakeholders.

The hydrogeological knowledge of Gran Canaria and Tenerife Islands can be considered as being between moderate and poor, even if they are some of the best known volcanic islands worldwide. This evaluation is relative to the economic and social importance of groundwater in them, in a semiarid environment and with important water demand for irrigation. No quantitative studies on the actual social and economic importance of groundwater are known. This probably asks for a greater effort in knowledge, monitoring and institutions than what exists currently, although no recent evaluation of the adequate degree and the associated economic and social effort to devote is available. Since at least two decades ago, the trend is to decrease effort, and what was done was largely reduced due to the current economic crisis, which is also a mental, social and governance crisis. A balance has to be found between expending studies and monitoring to reduce uncertainty and internalizing quite a large uncertainty in groundwater and water resource planning, which may make governability more complex and especially ask for norms and rules to be agreed upon. No approach for this goal is known for volcanic islands.

\section{Some Comments on Uncertainty in Groundwater Economic, Administrative and Social Aspects on the Canary Islands}

Hydrological uncertainty is not the only kind of uncertainty. Furthermore, the economic and social role and value of groundwater are uncertain and include important components of local resource governance. In the semiarid half of Spain, groundwater is an important water resource, often the most important [36]. It is the main source of water for agriculture (it normally takes the largest fraction of water resources), urban and tourist areas supply and for recreation, although some uses, like golf courses, have to use reclaimed water. Groundwater use is the best and most secure method to compensate for the reduced availability of surface water during droughts and even for the appropriate integration of desalinated sea water and reclaimed water in the water system. Groundwater may be also a source of brackish water for salinity reduction by membrane techniques. In many areas, water is considered a very 
important economic and social asset, and in some cases, it is really the most limiting factor. However, water is less important to the whole economy than what many people feel and many politicians and public administrator's claim, so some turmoil and concern regarding water availability is not always justified. It may be exaggerated or artificially raised. Concern about water quantity for human supply is often unsupported, as what is needed is only a fraction of the agricultural demand. Quality aspects are often more concerning than quantity ones, at least in semiarid Spain. What is really needed is a bold change of paradigm in water use. This is feasible without much stress by using groundwater resources, provided they are correctly managed and action does not start too late. Being aware of and knowing the involved uncertainty allow confronting future scenarios and planning the correct use of groundwater as a safety measure to cope with this and other aspects of uncertainty, including global and climate change.

All that has been said applies to the Canary Islands, in the reduced world of each island. Special care is needed on the main islands due to the greater weight of groundwater, currently and in the future, even if desalination and reuse currently play an important and growing role, although not always socially balanced. However, the actual situation is to some extent due to the erratic behavior of the islands' public administrations, besides an unclear and poorly-supported degree of intervention in what historically have been and still are private affairs, without defining clearly the roles, responsibilities and limits of each one. This is accompanied by a loss of technical capability that is substituted by a growing public and political intervention, while an efficient enough and decided counterbalance of water users and civil society is lacking or weak. This is not an uncommon situation in others areas of Southern Europe, but water scarcity worsen the results and urges a water agreement between the parts involved, including environmentalists, to improve action considering uncertainty.

Groundwater governance is part of water governance, and water governance is part of general governance. They have to achieve their duties in any circumstance and under uncertainty. To act, decide, agree and advance, solving the internal and external problems appearing in a given moment, considering external relationships, uncertainty has to be taken into account. This needs legal and administrative flexibility, but with clear rules to avoid arbitrary action, opportunism, corruption and misuse and dilapidation of human and economic resources and, at the same time, avoiding social conflicts and an excess of legal complaints. This flexibility is not the Spanish case, in part due to a long history of public intervention in territorial affairs under scarce resources. Governance requires norms, public administration and the involvement of water users' and the society in general, and it has to be capable of addressing and internalizing uncertainty.

A special characteristic of water resources on the islands of Gran Canaria and Tenerife, and also on La Palma to some extent, is the general existence of private water markets, since more than one century ago, mostly for groundwater, as groundwater was a private domain (now a public one, but all previous rights have been maintained) and obtaining groundwater was a costly and risky affair due to the expensive water works to be created. Aside from water owned by the user, a small proportion, water is mostly obtained in water markets. Besides, water shares in galleries and wells are traded. A complex transportation and storage system operates, so that the water produced in different places is given to those who bought a given quantity. Not only farmers get most of the water they need in these markets, but also towns, tourist areas and factories. Currently, the respective island water authorities produce water, mostly by seawater desalination, but also as waste water reclamation, and a large part is put into the market system. They also own some main canals and storage facilities. 
As the islands are isolated from each other, this prevents significant physical transfer of water among them (except between Lanzarote and Fuerteventura) and creates a special framework for governance.

The Water Act of the Canary Islands and the Spanish Water Act as a reference are too rigid and consolidate rigid rights for groundwater use [7] This does not favor governance when the values on which management is based are uncertain and under a situation in which the potential demand for groundwater is of the same magnitude or greater than the calculated values. In fact, this is one of the reasons for the difficulties found in the approval of the water districts' water plans in Spain and the latter disagreement for the part of groundwater producers and users. This is especially the case of Gran Canaria and Tenerife Islands. However, the existence of the private water trade and markets in them favor the flexible coupling between water offers and water demand, although with high prices (reflecting scarcity) and at the expenses of poorly-known interferences and damage to the environment. There are not enough studies dealing with the hydrological, economic and social effects on the environment and the services it provides to humans. It seems that the hypothetical restoration of environmental damage cannot be done at a proportionate cost relative to the expectable benefits, although these assertions are highly unsupported and uncertain.

The offer of water at a controlled price by the public administration does not directly affect management uncertainty, but it does indirectly through the economic distortion it produces in the water market system. Public prices often conceal subventions covered with public funds that could be used for other purposes in society. This does not imply that what has been said is good or bad, but rather a new form of uncertainty that is poorly valued or simply not considered.

To reduce the uncertainty associated with use and management (governance) of groundwater, up to the physically and economically possible point, studies and, especially, monitoring, periodical data analysis by experts, transparency and open access are required. It is at this point that groundwater users could and should be involved, jointly with the water administration, by largely participating in monitoring activities and their cost, up to the appropriate level, which depend on net benefits derived from groundwater by users and nature. This is often not taken into account, perhaps due to the lack of knowledge and/or conscience, the lack of institutions and the resistant parts of the water administration, which, at a general level (with some exceptions) does not fully understand the situation, is unprepared to confront it, wants to stay with what is strictly written in the norms or does not like losing its prerogatives. Furthermore, politicians, who still consider water as a political affair (although less so with time) do not address groundwater governance under uncertainty, as this is not on their minds, nor does the long delayed behavior of groundwater concern their short-term vision. The real potential for effective water and groundwater governance resides in active civil society institutions.

\section{Final Considerations for the Canary Islands}

In the current state of knowledge, it is not possible to provide validated evaluations of uncertainty of groundwater resources on Gran Canaria and Tenerife Islands, although some data and expert guesses allow some coarse approaches for the coefficient of variation (CV) for average values, as well as for annual values for the whole island. The estimation of recharge to aquifers, which is relatively important, may have a $\mathrm{CV}$ of $0.2-0.3$, even up to 0.4 as deduced preliminary from the atmospheric chloride deposition balance. It would be possible to refine groundwater resource evaluation considering 
abstraction, as is rather well known, with an optimistically estimated CV of 0.1 for Tenerife Island and perhaps 0.2 for Gran Canaria Island, but the component of discharge into the sea and especially the storage change are poorly known. Furthermore, groundwater resources may have at least a CV of $0.2-0.3$, or greater.

The incorporation of new water resources may decrease the uncertainty of total water resources, but groundwater is still a dominant term and foreseeably will continue to be in the coming decades.

The uncertainty of water costs and of the increasing trend of energy cost is added to groundwater quantity uncertainty, and also to quality, although this is not considered here. Furthermore, the uncertainty of the future availability of economic investments to maintain the water productivity of the galleries and wells system, which up to the present has mostly been of private origin, is an important and perhaps dominant uncertainty term. Furthermore, the future water demand is very uncertain, especially relative to the agricultural sector, which is the main water user. This sector depends greatly on the behavior of foreign markets, the concurrence of other nearby countries and other regions of Spain, the changing European agricultural policy and the importation of inputs needed for the production process. Farmers have no possibility of controlling these factors, except by improving efficiency, so groundwater in the case of the Canary Islands is the main term that they can act on to incur a marginal cost, even if water is a minor asset in their economic budget. Here, the right consideration of the uncertainty of groundwater resources plays an important role in deciding investments, future availability and costs that condition market concurrence for products and services.

These are the conditions under which aquifers have to be managed in a framework of new, but costly water resources being incorporated and the greater intervention of the public administration, but also of the greater pressure from water users. This has to be done in a context that conspicuously varies over time. Addressing and solving existing governance problems in a socially efficient way, at the least cost, needs a change of paradigm in the use of water. In this, the roles and responsibilities are re-distributed, although the public administration has the final decision, but with much greater institutional and economic involvement of water users and civil society in general. This requires transparency, adequate legislation, the abatement of corporate and personal resistance in water administration institutions, a bold change in the water use paradigm, open access to expert studies and much improved monitoring developed for each of the Canary Islands. These are new constraints and conditions to be developed and are needed in order to internalize uncertainty. All of this can be extended to most of the volcanic islands of Macaronesia and other similar areas. The main aspect is the balance between the cost of improving knowledge and monitoring beyond some levels to reduce the uncertainty in groundwater and water resource evaluation in time and space, as well as internalizing a given degree of uncertainty, even a large one, and acting accordingly to agreed rules and norms that assure governance. This is a main field for study and experimentation that has been poorly addressed until now on dry volcanic islands.

\section{Acknowledgments}

Project MASE (Groundwater Mining in Spain) provided the ideas and data. It received economic support from AQUALOGY, guidance by CETaqua and carried out by the Department of Geo-Engineering of the Technical University of Catalonia (UPC). Many Canarian experts have contributed to the project. The invitation to prepare this paper from the organizers of the Second 
Workshop on the Study, Use and Management of Water in Volcanic Terrains and Islands, held in Las Palmas de Gran Canaria in January 2014, is acknowledged. Two unknown reviewers and the editor have contributed very useful comments and corrections to improve the text and to extend it to comments not considered at the beginning, but maintaining the objective of contributing experience instead of contributing structured and detailed analysis of uncertainty.

\section{Author Contributions}

Emilio Custodio developed the MASE Project for the Canary Islands and wrote the paper with the help of María del Carmen Cabrera. Roberto Poncela, Luis Puga, Tatiana Cruz-Fuentes, Gema Naranjo and María del Carmen Cabrera have provided data, comments and advice about the Canary Islands hydrogeological, social and economic circumstances.

\section{Conflicts of Interest}

The authors declare no conflict of interest.

\section{References}

1. Beven, K. Facets of uncertainty: Epistemic uncertainty, nonstationarity, likelihood, hypothesis testing, and communication. Hydrol. Sci. J. 2015, doi:10.1080/02626667.2015.1031761.

2. Elshall, A.S.; Tsai, F.T.C. Constructive epistemic modeling of groundwater flow with geological structure and boundary condition uncertainty under Bayesian paradigm. J. Hydrol. 2014, 517, 105-119.

3. Guillaume, J.; Qureshi, M.; Jakeman, A. A structured analysis of uncertainty surrounding modeled impacts of groundwater-extraction rules. Hydrogeol. J. 2012, 20, 915-932.

4. Sanchez-Vila, X. Uncertainty and risk evaluation in a truly pluri-disciplinary framework, or when you are asked to provide exact solutions with virtually none information and you fail miserably. In Proceedings of the EGU General Assembly 2012, Vienna, Austria, 22-27 April 2012; p. 11666.

5. Alcalá, F.J.; Custodio, E. Natural uncertainty of spatial average aquifer recharge through atmospheric chloride mass balance in continental Spain. J. Hydrol. 2015, 524, 642-661.

6. Custodio, E. Aspectos hidrológicos, ambientales, económicos, sociales y éticos del consumo de reservas de agua subterránea en España: Minería del agua subterránea en España; AQUALOGY-CETaqua: Barcelona, Spain, 2015; pp. 1-550. (In Spanish)

7. Custodio, E. Comentarios sobre el Proyecto MASE en Canarias. In Estudio, Aprovechamiento y Gestión del Agua en Terrenos e Islas volcáNicas; Cabrera, M.C., Cruz-Fuentes, T., Mendoza-Grimón, V., Palacios-Díaz, M.P., Eds.; Instituto Geológico y Minero de España and International Association of Hydrogeologists-Spanish Group: Las Palmas de Gran Canaria, Spain, 2015; pp. 29-36. (In Spanish)

8. Custodio, E.; Cabrera, M.C. The Canary Islands. In Water, Agriculture and the Environment in Spain: Can We Square the Circle? de Stefano, L., Llamas, M.R., Eds.; CRC Press: London, UK, 2013; pp. 281-289. 
9. Cruz-Fuentes, T.; Heredia, J.; Cabrera, M.C.; Custodio, E. Behaviour of a small sedimentary volcanic aquifer receiving irrigation return flows: La Aldea, Gran Canaria, Canary Islands (Spain). Hydrogeol. J. 2014, 22, 865-882.

10. Cruz-Fuentes, T.; Cabrera, M.C.; Heredia, J.; Custodio, E. La explotación del Acuífero de La Aldea (Gran Canaria) desde el punto de vista de la Directiva Marco del Agua. In Estudio, Aprovechamiento y Gestión del Agua en Terrenos e Islas volcáNicas; Cabrera, M.C., Cruz-Fuentes, T., Mendoza-Grimón, V., Palacios-Díaz, M.P., Eds.; Instituto Geológico y Minero de España and International Association of Hydrogeologists-Spanish Group: Las Palmas de Gran Canaria, Spain, 2015; pp. 37-44. (In Spanish)

11. Crespo-Arribas, N.; Custodio, E.; Vázquez-Suñé, E. Caracterización hidrogeológica e hidrogeoquímica y modelación de flujo del Acuífero de Los Rodeos (Tenerife). In Estudio, Aprovechamiento y Gestión del agua en Terrenos e Islas Volcánicas; Cabrera, M.C., Cruz-Fuentes, T., Mendoza-Grimón, V., Palacios-Díaz, M.P., Eds.; Instituto Geológico y Minero de España and International Association of Hydrogeologists-Spanish Group: Las Palmas de Gran Canaria, Spain, 2015; pp. 167-174. (In Spanish)

12. Scanlon, B.R.; Healy, R.W.; Cook, P.G. Choosing appropriate techniques for quantifying groundwater recharge. Hydrogeol. J. 2002, 10, 18-39.

13. Lerner, D.N.; Issar, A.S.; Simmers, I. Groundwater Recharge. A Guide to Understanding and Estimating Natural Recharge; International Association of Hydrogeologists, Ed.; International Contributions to Hydrogeology 8; Heise: Hannover, Germany, 1990; pp. 1-345.

14. De Vries, J.J.; Simmers, I. Groundwater recharge: An overview of processes and challenges. Hydrogeol. J. 2002, 10, 5-17.

15. Custodio, E.; Llamas M.R. Hidrología Subterránea; Ediciones Omega: Barcelona, Spain, 1976; pp. 1-2350. (In Spanish)

16. Custodio, E.; Llamas, M.R.; Samper, J. (Eds.) La Evaluación de la Recarga a los Acuíferos en la Planificación Hidrológica; Instituto Tecnológico Geo-Minero: Madrid, Spain, 1997; pp. 1-455. (In Spanish)

17. Healy, R.W. Estimating Groundwater Recharge; Cambridge University Press: Cambridge, UK, 2010; pp. 1-264.

18. Cruz-Fuentes, T.; Cabrera, M.C.; Heredia, J.; Custodio, E. Groundwater salinity and hydrochemical processes in the volcano-sedimentary aquifer of La Aldea, Gran Canaria, Canary Islands, Spain. Sci. Total Environ. 2014, 484, 154-166.

19. Samper, J. Evaluación de la recarga por la lluvia mediante balances de agua: Utilización, calibración e incertidumbres. Bol. Geol. Min. 1998, 109, 31-54. (In Spanish)

20. Samper, J.; Huguet, L.1.; Ares, J.; García-Vera, M.A. User's Guide VisualBALAN v.2.0: Código Interactivo Para la Realización de Balances Hidrológicos y la Estimación de la Recarga; ENRESA: Madrid, Spain, 2005; pp. 1-150. (In Spanish) 
21. Naranjo, G.; Cabrera, M.C.; Cruz-Fuentes, T.; Martín, L.F.; Custodio, E. Cuantificación de la recarga natural al acuífero del Norte de Gran Canaria mediante el balance diario de agua en el suelo. In Estudio, Aprovechamiento y Gestión del Agua en Terrenos e Islas Volcánicas; Cabrera, M.C., Cruz-Fuentes, T., Mendoza-Grimón, V., Palacios-Díaz, M.P., Eds.; Instituto Geológico y Minero de España and International Association of Hydrogeologists-Spanish Group: Las Palmas de Gran Canaria, Spain, 2015; pp. 247-254. (In Spanish)

22. Custodio, E. Estimation of aquifer recharge by means of atmospheric chloride deposition balance. Contrib. Sci. 2009, 5, 81-97.

23. Cabrera, M.C.; Naranjo, G.; Cruz-Fuentes, T.; Hernández-Quesada, P.; Benavides, A.; Estévez, E.; Martín, L.F.; Custodio, E. Aplicación del balance de cloruros para la estimación de la recarga natural al acuífero del norte de Gran Canaria. In Hidrogeología y Recursos Hidráulicos, Vol. XXX; Fernández-Uría, A., Ed.; Instituto Geológico y Minero de España: Madrid, Spain, 2013; pp. 499-508. (In Spanish)

24. Naranjo, G.; Cruz-Fuentes, T.; Cabrera, M.C.; Martín, L.F.; Custodio, E. Avances en la estimación de la recarga natural mediante la aplicación del método del balance de cloruros atmosféricos al acuífero del norte de Gran Canaria. In II Congreso Ibérico de Aguas Subterráneas; Gómez-Hernández, J., Rodrigo-Ilarri, J., Eds.; Universidad Politécnica de Valencia: Valencia, Spain, 2014; pp. 217-232. (In Spanish)

25. Marrero-Díaz, R.; Pérez, N.M.; Alcalá, F.J.; Melián, G.V.; Padrón, E.; Padilla, G.D. Estimación de la recarga mediante balance de masas de cloruro atmosférico en la Caldera de Las Cañadas, Tenerife, Islas Canarias. In Estudio, Aprovechamiento y Gestión del Agua en Terrenos e Islas Volcánicas; Cabrera, M.C., Cruz-Fuentes, T., Mendoza-Grimón, V., Palacios-Díaz, M.P., Eds.; Instituto Geológico y Minero de España and International Association of Hydrogeologists-Spanish Group: Las Palmas de Gran Canaria, Spain, 2015; pp. 207-214. (In Spanish)

26. Alcalá, F.J.; Custodio, E. Spatial average aquifer recharge through atmospheric chloride mass balance and its uncertainty in continental Spain. Hydrol. Process. 2014, 28, 218-236.

27. Espinosa, S. Estimación de la Recarga Media Anual de Acuíferos: Aplicación al Baix Ebre. Ph.D. Thesis, Department of Geo-Engineering, Technical University of Catalonia (UPC), Barcelona, Spain, 2014; pp. 1-286.

28. Ministerio de Obras Públicas y Urbanismo y la UNESCO (MOP-UNESCO). Estudio científico de los recursos de agua en las Islas Canarias; Project SPA/69/515 MOP (DGOH)-PNUD (UNESCO); Dirección General de Obras Hidráulicas-UNESCO: Madrid, Spain, 1975. (In Spanish)

29. Cabrera, M.C.; Custodio, E. La investigación hidrogeológica en Canarias desde el Proyecto SPA-15. In El conocimiento de los recursos hídricos en Canarias cuatro décadas después del Proyecto Canarias SPA-15; Cabrera, M.C., Jiménez, J., Custodio, E., Eds.; International Association of Hydrogeologists-Spanish Group: Las Palmas de Gran Canaria, Spain, 2011; pp. 109-116.

30. Custodio, E. Evolución del conocimiento hidrogeológico e hidrológico de Canarias. In El Conocimiento de los Recursos Hídricos en Canarias cuatro Décadas Después del Proyecto Canarias SPA-15; Cabrera, M.C., Jiménez, J., Custodio, E., Eds.; International Association of Hydrogeologists-Spanish Group: Las Palmas de Gran Canaria, Spain, 2011; pp. 5-12. (In Spanish) 
31. Cruz-Fuentes, T.; Naranjo Ayala, G.; Cabrera Santana, M.C.; Custodio, E. Estimación de la escorrentía superficial mediante la generación automática del número de curva con un SIG: aplicación al norte de Gran Canaria (Islas Canarias, España). In II Congreso Ibérico de Aguas Subterráneas; Gómez-Hernández, J., Rodrigo-Ilarri, J., Eds.; Universidad Politécnica de Valencia: Valencia, Spain, 2014; pp. 217-232. (In Spanish)

32. Herrera, C.H.; Custodio, E. Groundwater flow in a relatively old oceanic volcanic island: The Betancuria area, Fuerteventura Island, Canary Islands, Spain. Sci. Total Environ. 2014, 496, 531-550.

33. Carrera, J.; Alcolea, A.; Medina, A.; Hidalgo, J.; Slooten, L.J. Inverse problem in hydrogeology. Hydrogeol. J. 2005, 13, 206-222.

34. Shin, M.-J.; Guillaume, J.H.A.; Croke, B.F.W.; Jakeman, A.J. A review of foundational methods for checking the structural identifiability of models: Results for rainfall-runoff. J. Hydrol. 2015, 52, $1-16$.

35. Gupta, H.V.; Clark, M.P.; Vrugt, J.A.; Abramowitz, G.; Ye, M. Towards a comprehensive assessment of model structural adequacy. Water Resourc. Res. 2012, 48, W08301.

36. Llamas, M.R.; Custodio, E.; de la Hera, A.; Fornés, J.M. Groundwater in Spain: Increasing role, evolution, present and future. Environ. Earth Sci. 2015, 73, doi:10.107/s12665-014-4004-0.

(C) 2015 by the authors; licensee MDPI, Basel, Switzerland. This article is an open access article distributed under the terms and conditions of the Creative Commons Attribution license (http://creativecommons.org/licenses/by/4.0/). 